\title{
Hemodiyaliz Hastalarında Konfor Düzeyinin İncelenmesi $\infty$
}

\author{
Turgay GÜLAY ${ }^{1}$, Çiğdem ÖZDEMIR ELER ${ }^{2}$, Şeyda ÖKDEM ${ }^{3}$, Ebru AKGÜN ÇITAK ${ }^{4}$
}

öz

Amaç: Hemodiyaliz tedavisi alan hastalarda konfor düzeyinin incelenmesidir.

Gereç ve Yöntem: Tanımlayıcı olarak yapılan araştırma, Ekim-Aralık 2018 tarihleri arasında, hemodiyaliz tedavisi alan 262 hasta ile yapılmıştır. Veriler "Hasta Tanıtım Formu" ve "Hemodiyaliz Konfor Ölçeği kullanılarak toplanmıştır. Araştırmadan elde edilen veriler SPSS (Statistical Package For Social Sciences) 25 programı kullanılarak; sayı, yüzde ve frekans dağııımları ile değerlendirilmiştir. Analizlerde bağımsız gruplarda $t$ testi ve tek yönlü varyans analizinden yararlanılmıştır. Çalışmada kullanılan ölçeğin iç tutarlığını değerlendirmek için Cronbach alfa katsayısı 0.75 olarak bulunmuştur. Çalışmada anlamlılık düzeyi $p<0.05$ olarak kabul edilmiştir.

Bulgular: Çalışmaya katılan hastaların \%59.5'i erkek, \%30.5'i 40-59 yaş aralığında ( $\bar{x}=60.7 \pm 14.48$, min:18-max:92), \%37'si emekli, $\% 70.2^{\prime}$ sinin gelir durumu orta düzeydedir. Hastaların $\% 77.5^{\prime}$ inin haftada 3 seans diyaliz tedavisi aldığı, \%65.6'sının vasküler giriş yolunun arteriovenöz fistül olduğu saptanmıştır. Hastaların Hemodiyaliz Konfor Ölçeği üstesinden gelme alt boyutu puan ortalaması $16.01 \pm 4.81$, rahatlama alt boyutu puan ortalaması $9.16 \pm 3.70$ ve ölçek puan ortalaması $25.18 \pm 7.03$ olarak bulunmuştur.

Sonuç: Hemodiyaliz hastalarının konfor düzeyinin orta olduğu saptanmıştır.

Anahtar kelimeler: Hemodiyaliz, konfor, son dönem böbrek yetmezliği

\begin{abstract}
Examining the Comfort Level of Hemodialysis Patients Aim: This study was conducted to evaluate the comfort level of patients receiving hemodialysis treatment.

Material and Methods: This descriptive study was conducted with 262 patients receiving hemodialysis treatment between October and December 2018. Data were collected using "Patient Identification Form" and "Hemodialysis Comfort Scale. The data obtained from the study were analyzed by using SPSS (Statistical Package for Social Sciences) 25 program with number, percentage, independent samples $t$ test and one way ANOVA. The Cronbach alpha coefficient of the scale used in the study was found to be 0.75 . In the study, the significance level was accepted as $p<0.05$. Results: $59.5 \%$ of the patients were male, $30.5 \%$ were between the ages of $40-59(\bar{x}=60.7 \pm 14.48$, min:18-max: 92$), 37 \%$ were retired, $70.2 \%$ of them had a moderate income level. It was found that $77.5 \%$ of the patients received 3 sessions of dialysis treatment per week and $65.6 \%$ of them had arteriovenous fistula. The mean score of subscale "overcoming" was $16.01 \pm 4.81$, the mean score of subscale "relief" was $9.16 \pm 3.70$ and the total scale mean score was 25.18 \pm 7.03 .

Conclusion: The comfort level of hemodialysis patients was found to be moderate.

Keywords: Comfort, hemodialysis, end stage renal disease
\end{abstract}

${ }^{1}$ Dr. Öğr. Üyesi Başkent Üniversitesi Sağlık Hizmetleri Meslek Yüksekokulu, Ankara, Türkiye, E-mail: gturgay_gmh@hotmail.com, Tel: 0312 246 66 66/1709, ORCID: 0000-0003-2790-1426

º̈ğr. Gör. Başkent Üniversitesi Sağlık Hizmetleri Meslek Yüksekokulu, Ankara, Türkiye, E-mail: cigdemo@baskent.edu.tr, Tel: 0312 246 66 66/1709, ORCID:0000-00025900-4220

${ }^{3}$ Dr. Öğr. Üyesi Başkent Üniversitesi Sağlık Hizmetleri Meslek Yüksekokulu, Ankara, Türkiye, E-mail: okdems@ baskent.edu.tr, Tel: 0312 246 66 66/6716, ORCID:00000002-4534-8081

${ }^{4}$ Doç. Dr. Başkent Üniversitesi Sağlık Bilimleri Fakültesi, Ankara, Türkiye, E-mail: citak@baskent.edu.tr, Tel: 0312 246 66 66/2139, ORCID:0000-0002-0484-4687 Geliş Tarihi: 26 Şubat 2019, Kabul Tarihi 02 Mayıs 2020

Atıf/Citation: Gülay T, Özdemir Eler Ç, Ökdem Ş, Akgün Çıtak E. Hemodiyaliz Hastalarında Konfor Düzeyinin İncelenmesi. Hacettepe Üniversitesi Hemşirelik Fakültesi Dergisi 2020; 7(2): 122-129. DOI: 10.31125/hunhemsire.763155 


\section{Giriş}

Son Dönem Böbrek Yetmezliği (SDBY), böbrek fonksiyonlarının geri dönüşsüz kaybı sonucunda, glomerüler filtrasyon hızının (GFH) 5-10 ml/dk'ya düşmesi ve renal replasman tedavi (RRT) seçeneklerinden uygun olanının başlanmasının gerektiği önemli bir halk sağlığı sorunudur ${ }^{1,2}$. Ülkemizde Türkiye Cumhuriyeti Sağlık Bakanlığı ve Türk Nefroloji Derneği ortak raporuna göre, 2018 yılı sonu itibariyle toplam 71.055 hastaya RRT uygulanmaktadır. En sık uygulanan RRT tipi ise $\% 74,82$ oranla hemodiyaliz (HD)'dir ${ }^{3}$.

Günümüzde HD alanındaki ilerlemeler, SDBY hastalarının yaşam sürelerinin uzamasına yol açmıştır. Fakat bu gelişmelere bağı hastalık ve tedavi ile ilişkili birçok fiziksel ve psikososyal semptom gelişmektedir. Konstipasyon, bulantı, kusma, diyare, iştahsızlık, kas krampları, ödem, ciltte kuruluk, kaşıntı, uyku problemleri, ağrı, huzursuzluk, cinsel işlev bozukluğu gibi deneyimlenen bu semptomlar hastada fiziksel, sosyal, ekonomik, psikolojik sorunların ortaya çıkmasına neden olmakta ve hastaların öz bakım gücünde, yaşam kalitesinde, konforunda azalmaya neden olabilmektedir ${ }^{4,5}$. HD hastasında görülen kaşıntıya bağı bireyde uyku düzeni bozukluğu, fiziksel ve zihinsel yorgunluk, sosyal izolasyon görüldüğü, dolayısıyla bireyin konfor düzeyinin etkilendiği görülmektedir ${ }^{6}$. Deneyimlenen ağrı semptomu, HD tedavisine uyumu azaltmakta, yaşam kalitesini ve konforu olumsuz yönde etkilemektedir. Yorgunluk ise HD hastasının günlük yaşam aktivitelerini, öz bakım gücünü etkileyerek bireyin konforunu etkilemektedir?.

HD hastasının konforunu etkileyen birçok faktör bulunmaktadır. Tedavi için sürekli bir diyaliz merkezine ulaşmak zorunda olmak, HD seans süresinde hareketlerin kısıtlanması, HD tedavisine bağı bireysel bağımsızlığın azalması, iş uyumunda bozulma ve sosyal ilişkilerde bozulma pek çok faktörden biridir ve bunlar hastaların deneyimlediği günlük konforlarını azalmaktadır ${ }^{8,9}$. Bu nedenle HD hastasının konforunun sağlanması ve yaşam kalitesinin artırılması önemlidir. Bunun için hastanın semptom kontolünü güçlendirecek etkin bir bakımın verilmesi gerekmektedir. HD hastasının çoğunlukla haftada 3 gün ortalama 4 saat süren tedavisi için diyaliz merkezinde olduğu gözönünde bulundurulduğunda beklenen etkin bakımın sağlanmasında hemşirelerin rolünün önemi daha belirginleşmektedir ${ }^{10}$. Bu kapsamda hem tedavinin başlangııında hemde ilerleyen dönemlerinde hemşirelerin iyi bir izleme ve etkili bir semptom yönetimi ile HD hastasının konfor düzeyinin yükseltilebildiği bilinmektedir11,12.

Konfor; bireylerin karşılanması gereken temel insan gereksinimlerindendir. Hemşirelikte güncel bir öneme sahip olan konfor kavramı, hastanın konforunun sağlanmasının kaliteli bakımın bir parçası olarak kabul edilmektedir. Hemşire, hasta bireyin konfor gereksinimlerini tanılaması, bu gereksinimlerin karşılanmasına yönelik hemşirelik bakımı girişimlerini planlaması, uygulaması, uygulama sonrası hasta bireyin konfor düzeyini değerlendirebilmelidir ${ }^{13}$. Hastanın konfor gereksiniminin başarılı bir şekilde karşılanması, hemşirelik tanısının doğru belirlenmesine bağlıdır. Kuzey Amerika Hemşirelik Tanılama Derneği'nin (North American Nursing Diagnosis Assocation-NANDA) belirlediği "Rahatlıkta/Konforda Bozulma" tanısın da; hasta da görülen ağrı, bulantı, kaşıntı gibi rahatsız edici uyarana tepki olarak rahatsızlık duygusu yaşayan bireyin konforunda bozulma görülebildiği belirtilmektedir ${ }^{14}$.

Yapılan literatür incelemesinde, HD tedavisi alan hastaların konforlarını etkileyen semptomlar ile ilgili çeşitli hemşirelik araştırmaları bulunmaktadır ${ }^{11,15}$. HD hastalarının konforlarını azaltan bu semptomlar; yorgunluk ${ }^{16,17}$, ağrı12,18, bulantı-kusma ${ }^{19}$, konstipasyon-diyare ${ }^{20,21}$, kaşıntı ${ }^{12}$, uyku problemleri22,23 olarak tanımlanmıştır. Semptom kontrolünün iyi yapılabilmesi, etkin bir bakım verilmesi, hasta eğitiminin ve uygulanabilecek girişimlerin planlanması için hastaların konfor düzeylerinin belirlenmesi oldukça önemlidir ${ }^{24}$. Bu nedenle bu çalışma, planlanacak çalışmalara, uygulanacak girişimlere katkı sağlaması adına, hemodiyaliz hastalarının konfor düzeyinin incelenmesi amacıyla yapılmıştır.

\section{Araştırma Soruları}

Hemodiyaliz hastalarının genel konfor düzeyi nasıldır? Hemodiyaliz hastalarının demografik özelliklerine göre konfor düzeyi nasıldır?

Hemodiyaliz hastalarının hastalığa ilişkin özelliklerine göre konfor düzeyi nasıldır?

\section{GEREÇ ve YÖNTEM}

\section{Araştırmanın Türü}

Tanımlayıcı nitelikte olan bu çalışma, hemodiyaliz hastalarının konfor düzeyinin belirlenmesi amacıyla yapılmıştır.

\section{Araştırmanın Yeri ve Zamanı}

Bu araştırma, Ekim - Aralık 2018 tarihleri arasında; Başkent Üniversitesi Hastanesi'ne bağlı iki diyaliz merkezinde HD tedavisi alan hastalar ile yapılmıştır. Diyaliz merkezinin birinde $\mathbf{2 2 0}$ hasta tedavi görmektedir. Bu merkez üç adet on iki yataklı salon, bir adet Hepatit $B$ ve $C$ hastalarına ait üçer yataklı salonla hizmet vermektedir. Ayrıca ünitede acil müdahale odası, doktor odası, ofis, teknisyen odası, personel giyinme odaları, hasta giyinme odaları, bekleme salonu ve konferans salonu bulunmaktadır. Bir diğer diyaliz merkezinde ise 140 hasta tedavi görmekte, bir adet 16 yataklı salon, bir adet ikişer yataklı salon, bekleme salonu, doktor odası, hemşire odası ve giyinme odası bulunmaktadır. Hemodiyaliz işlemi genellikle haftada $3 \mathrm{kez}$ ve her seans 4 saat olacak şekilde uygulanır. HD seansı süresince hastalar tercihleri doğrultusunda her yatak başında bulunan plazma tv, kişiye özel kulaklık ile tv izleyebilmekte, müzik dinleyebilmekte, diğer hastalarla sohbet edebilmekte ya da dinlenmektedirler. Hastaların eğitim ihtiyaçları sağlık profosyonelleri tarafından belirlenip, belirlenen ihtiyaçlar doğrultusunda hasta kendini iyi hissettiği sürede ya da seans sonunda eğitim salonunda grup eğitimleri yürütülmektedir. Her iki diyaliz merkezinde Diyaliz Merkezleri Hakkında Yönetmeliği'ne göre her 5 cihaz için 1 sertifikalı diyaliz hemşiresi ya da diyaliz teknikeri çalışmaktadır ${ }^{25}$ 


\section{Araştırmanın Evreni ve Örneklemi}

Araştırmanın evrenini veri toplama tarihleri arasında ilgili hastanenin diyaliz merkezlerinde tedavi alan 360 hasta oluşturmuştur. Araştırmanın örneklemine dahil etme kriterleri; gönüllü olma, 18 yaş ve üstünde olma, bilinç düzeyi (veri toplama araçlarındaki ifadeleri anlama yetisine sahip olma), oryantasyonu yerinde olma, işitme sorunu yaşamama ve en az 6 aydır HD tedavisi alma olarak belirlenmiştir. Araştırmanın örnekleme dahil etme kriterlerine göre; 360 hastanın 4'ünün 18 yaş ve üstünde olmadığı, 8'inin 6 aydan az HD tedavisi aldığı ve 86'sının da çalışmaya katılmak istemediği belirlenmiştir. Dahil edilme kriterlerine uyan 262 hasta ile çalışma tamamlanmıştır.

\section{Veri Toplama Araçları}

Çalışmanın verileri, araştırmacı tarafından ilgili literatür12,23,26,27,28 doğrultusunda hazırlanmış "Hasta Tanıtım Formu" ve "Hemodiyaliz Konfor Ölçeği (HDKÖ)" kullanılarak toplanmıştır. Hasta Tanıtım Formu; hastaların sosyo-demografik özelliklerini ve hastalığa ilişkin özelliklerini içeren 11 sorudan oluşmaktadır. Hasta tanıtım formunda; hastanın yaşı, cinsiyeti, medeni durumu, eğitim durumu, gelir durumu, sosyal güvencesi, mesleği, kaç ay/yıl HD tedavisi aldığı, damara erişim yolu, haftalık diyaliz seans sayısı ve sekonder bir hastalığın varlığına ilişkin soruları içermektedir.

Hemodiyaliz Konfor Ölçeği (HDKÖ); Kolcaba tarafından geliştirilen Genel Konfor Ölçeği ve sonrasında belirli durumlara özgü geliştirilen konfor ölçeklerinden yararlanılarak Şahin-Orak ve arkadaşları tarafından 2017 yılında geçerlik ve güvenirliği yapılan beşli likert tipinde bir ölçek olup, 9 madde ve 2 alt boyuttan oluşmaktadır. Ölçeğin 4. maddesine verilen yanıtlardan "hiçbir zaman"1 puan, "çok nadir" 2 puan, "bazen" 3 puan, "çok sık" 4 puan ve "her zaman" 5 puan olarak puanlanmaktadır. Diğer maddelere $(1-3,5-9)$ verilen yanıtlardan "hiçbir zaman" 5 puan, "çok nadir" 4 puan, "bazen" 3 puan, "çok sık" 2 puan ve "her zaman" 1 puan olarak puanlanmaktadır. Ölçeğin "Rahatlama" (7-9. maddeler) ve "Üstesinden gelme" (1-6. maddeler) olmak üzere iki alt boyutu bulunmaktadır. Rahatlama alt boyutundan en az 3.00 ve en çok 15.00 puan alınabilmekte; üstesinden gelme alt boyutundan ise en az 7.00 ve en çok 30.00 puan alınabilmektedir. HDKÖ'den alınacak en düşük puan 9, en yüksek puan $45^{\prime}$ tir. Alınan puan 45'e yaklaştıkça konfor seviyesi yükselmektedir. Ölçeğin Cronbach's alfa güvenirlik katsayısı ise $0.87^{\prime}$ dir $^{27}$. Bu çalışmada da HDKÖ’nün cronbach alfa iç tutarlılık katsayısı 0.75 olarak bulunmuştur.

\section{Araştırmanın Uygulanması}

Veriler Ankara ilinde bulunan iki özel diyaliz merkezinde, araştırmacılar tarafından yüz yüze görüşme yöntemi ile ortalama 10 dakikada toplanmıştır. Anketler, kendini iyi hisseden hastalara HD tedavi seansı ilk saati içinde araştırmacılar tarafından hastalara sorular okunarak doldurulmuştur. Kendini iyi hissetmediğini ifade eden hastalara anketler, hastaların kendilerini iyi hissettiklerini ifade ettikleri zaman dilimi içerisinde araştırmacılar tarafından doldurulmuştur.

\section{Verilerin Değerlendirilmesi}

Araştırmadan elde edilen veriler bilgisayarda SPSS (Statistical Package For Social Sciences) 25 programı kullanılarak sayı, yüzde ve frekans dağılımları ile değerlendirilmiştir. Verilerin normallik kontrolüne Kolmogorow Simirnov testi ile bakılmıştır $(p>0,05)$. İstatiksel analizlerde bağımsız gruplarda t testi ve tek yönlü varyans analizinden yararlanılmıştır. Çalışmada kullanılan ölçeğin iç tutarlığını değerlendirmek için Cronbach alfa katsayısı kullanılmıştır. Çalışmada anlamlılık düzeyi $p<0.05$ olarak kabul edilmiştir.

\section{Araştırmanın Etik Boyutu}

Araştırmanın uygunluğu ve yapılabilmesi için Başkent Üniversitesi Etik Kurulundan etik onam (10/10/2018, KA18/289) ve araştırmanın yürütülebilmesi için Başkent Üniversitesi Hastanesi Başhekimliğinden kurum izni alınmıştır. Araştırmada insan olgusunun kullanımında bireysel hakların korunması gerektiğinden "isteklilik, gönüllülük" ilkesi ışığında "Bilgilendirilmiş/Aydınlatılmış Onam" koşulu yerine getirilmiştir. HDKÖ kullanım izni, Nuray Şahin Orak'dan e-posta yoluyla alınmıştır.

\section{BULGULAR}

Çalışmaya katılan hastaların \%59.5'inin erkek, \%30.5'inin 4059 yaş aralığında ( $\bar{x}=60.7 \pm 14.48$, min:18-max:92), \%35.8'inin ilkokul mezunu olduğu görülmektedir. Katılımcıların \%37'si emekli olup, \%95.4'ünün sosyal güvencesi bulunmakta ve \%70.2'sinin geliri giderine eşittir. Çalışmaya katılan hastaların \%77.5'inin haftada 3 seans diyaliz tedavisi aldığı, \%65.6'sının vasküler giriş yolunun arteriovenöz fistül olduğu görülmektedir. Çalışmaya katılan hastaların \%35.5'inin hemodiyaliz tedavisine başlama zamanının 1-3 yıl olduğu ve \%55'inin böbrek yetmezliği dışında kronik bir hastalığının olduğu saptanmıştır (Tablo 1).

Tablo 1. Hemodiyaliz Hastalarının Tanımlayıcı Özelliklere Göre Dağılımı ( $n=262)$

\begin{tabular}{|l|c|c|}
\hline Özellik & $\mathbf{n}$ & $\%$ \\
\hline Cinsiyet & 106 & \\
Kadın & 156 & 40.5 \\
Erkek & & 59.5 \\
\hline Yaş & 26 & \\
39 ve altı & 80 & 9.9 \\
$40-59$ & 80 & 30.5 \\
$60-69$ & 76 & 30.5 \\
70 ve üzeri & & 29.9 \\
\hline Medeni Durum & 203 & \\
Evli & 59 & 77.5 \\
Bekar & & 22.5 \\
\hline Eğitim Durumu & 17 & \\
Okur Yazar Değil & 94 & 6.5 \\
Ilkokul & 22 & 35.8 \\
Ortaokul & 44 & 8.4 \\
Lise & 85 & 16.8 \\
Üniversite & & 32.5 \\
\hline Sosyal Güvence & 250 & 95.4 \\
Evet & 12 & 4.6 \\
Hayır & & \\
\hline Aylık Gelir Durumu & 51 & 19.5 \\
Gelir Giderden Az & 184 & 70.2 \\
Gelir Gidere Denk & 27 & 10.3 \\
Gelir Giderden Fazla & & \\
\hline
\end{tabular}


Tablo 1. Hemodiyaliz Hastalarının Tanımlayıcı Özelliklere Göre Dağııımı (n= 262) (devamı)

\begin{tabular}{|l|c|c|}
\hline Meslek & 23 & 8.8 \\
Memur & 14 & 5.2 \\
Isş̧i & 97 & 37.0 \\
Emekli & 72 & 27.5 \\
Ev Hanımı & 17 & 6.5 \\
Serbest Meslek & 13 & 5.0 \\
Isşsiz & 26 & 10.0 \\
Diğer & $\mathbf{n}$ & $\mathbf{\%}$ \\
\hline Hastalığa İlişkin Özellikler & & \\
\hline Hemodiyaliz sıklığı & 203 & 77.5 \\
Haftada 3 seans & 50 & 19.1 \\
Haftada 2 seans & 9 & 3.4 \\
Haftada 1 seans & & \\
\hline Vasküler Giriş Yolu & 172 & 65.6 \\
Arteriovenöz Fistül & 6 & 2.3 \\
Arteriovenöz Greft & 84 & 32.1 \\
Vasküler Kateterizasyon & & \\
\hline Hemodiyaliz Tedavisine Başlama & & \\
Zamanı & 93 & 35.5 \\
1-3 yıl & 62 & 23.7 \\
4-6 yıl & 33 & 12.6 \\
7-9 yıl & 40 & 15.3 \\
10-12 yıl & 34 & 13.0 \\
13 yıl ve üzeri & & \\
\hline Sekonder Hastalık & 118 & 45.0 \\
Evet & 144 & 55.0 \\
\hline Hayır & $\mathbf{2 6 2}$ & $\mathbf{1 0 0 . 0}$ \\
\hline Toplam & & \\
\hline & & \\
\hline
\end{tabular}

Tablo 2'de hemodiyalizde konfor ölçeği toplam puan ortalaması ile alt boyutlarının puan ortalamaları yer almaktadır. Hastaların üstesinden gelme alt boyutu puan ortalaması $16.01 \pm 4.81$, rahatlama alt boyutu puan ortalaması $9.16 \pm 3.70$ ve toplam ölçek puan ortalaması 25.18 \pm 7.03 olarak bulunmuştur.

Tablo 2. Hemodiyalizde Konfor Ölçeği Toplam Puan Ortalaması ve Alt Boyutlarının Puan Ortalamaları $(n=262)$

\begin{tabular}{|l|c|c|c|}
\hline & Minumum & Maksimum & Ortalama \pm SS \\
\hline $\begin{array}{l}\text { Üstesinden } \\
\text { Gelme }\end{array}$ & 6.00 & 28.00 & $16.01 \pm 4.81$ \\
\hline Rahatlama & 3.00 & 15.00 & $9.16 \pm 3.70$ \\
\hline Toplam & 9.00 & 42.00 & $25.18 \pm 7.03$ \\
\hline
\end{tabular}

Tablo 3' de hemodiyaliz hastalarının tanımlayıcı özellikleri ve hemodiyalizde konfor ölçeği puan ortalamalarının karşılaştırılması yer almaktadır. HDKÖ puan dağılımlarına bakıldığında; erkek hastaların rahatlama boyutu puan ortalaması (9.30 \pm 3.91$)$ ile üstesinden gelme boyutu puan ortalaması (16.32 \pm 4.52$)$ istatistiksel olarak anlamlı bulunmuştur $(p<0.05)$. Yaş, medeni durum, eğitim durumu, sosyal güvence, meslek değişkenleri ile ölçek puan ortalamaları arasında anlamlı bir fark bulunmamıştır ( $p>0.05)$. Gelir durumu ile HDKÖ üstesinden gelme alt boyutu puan ortalaması ve ölçek toplam puan ortalaması arasında istatistiksel olarak anlamlı fark bulunmuştur $(p<0.05)$.
Tablo 4'de hemodiyaliz hastalarının hastalığa ilişkin özellikleri ve hemodiyalizde konfor ölçeği puan ortalamalarının karşılaştırılması yer almaktadır. Tablo incelendiğinde; vasküler giriş yolu greft olan hastaların üstesinden gelme alt boyutu puan ortalaması $(19.83 \pm 5.07)$ istatistiksel olarak anlamlı bulunmuştur $(p<0.05)$. Haftalık

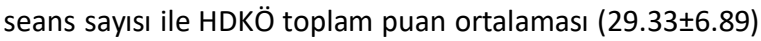
arasındaki fark istatistiksel olarak anlamlı bulunmuştur $(p<0.05)$. Sekonder bir hastalığı olanların, HDKÖ üstesinden gelme alt boyut puan ortalaması $(15.30 \pm 4.92)$ istatistiksel olarak anlamlı bulunmuştur $(p<0.05)$.

\section{TARTIŞMA}

Bu çalışma, HD tedavisi alan hastalarda konfor düzeyinin incelenmesi amacıyla yapılmıştır. Çalışmamızda HD hastalarının konfor düzeyinin orta düzeyde olduğu saptanmıştır.

Konfor, hasta ve ailesinin yüksek yaşam kalitesine sahip olmasında etken olan önemli bir kavramdır. Yaş, medeni durum, eğitim seviyesi, cinsiyet, gelir durumu, sosyal destek ve eşlik eden başka bir hastalığın olması gibi özelliklerin de konforu etkilediği bildirilmektedir ${ }^{29}$. Çalışmamızdaki hastaların tanımlayıcı özellikleri ile konfor puanları karşılaştırıldığında yaş, medeni durum, eğitim durumu, sosyal güvence ve meslek ile istatistiksel olarak anlamlı bir fark bulunmazken; erkek hastaların HDKÖ rahatlama alt boyutu puan ortalaması ve HDKÖ üstesinden gelme alt boyutu puan ortalamasının kadınlara göre daha yüksek olduğu bulunmuştur. Estridge ve arkadaşlarının (2018), 51 HD tedavisi alan hasta ile yaptıkları çalışmada, kadın hastaların genel konfor ölçeği puan ortalamalarının erkeklere göre biraz yüksek olduğu saptanmıştır ${ }^{30}$. Toplumda cinsiyet rolü olarak bilinen, kadınlara yüklenen sorumlulukların; kadınların konfor düzeyinin erkeklere oranla daha düşük seviyede olmasına neden olduğu düşünülmektedir. Kadın ve erkeklerin konfor düzeyleri açısından litaratür ile karşılaştırıldığında benzerlik olmadığı görülmektedir. $\mathrm{Bu}$ durumun çalışma gruplarının farklılıklarından kaynaklandığı düşünülmektedir.

Konfor gereksinimi olan birey ancak bu gereksinim karşılandığında sorunların üstesinden gelme becerisinde başarılı olmaktadır. Çalışkan'ın (2018), HD hastaları ile yaptığı çalışmada genel konfor ölçeğinin üstesinden gelme alt boyutunda hastaların desteğe ihtiyaçlarının olduğu ifade edilmiştir ${ }^{12}$. Çalışmamızda gelir durumu yüksek hastalarda; HDKÖ üstesinden gelme alt boyutu puan ortalaması ve HDKÖ puan ortalaması istatistiksel olarak yüksek bulunmuştur. Eğitim seviyesi, gelir durumu gibi özelliklerin yüksek olması, HDKÖ üstesinden gelme alt boyutunda olumlu etkisi bulunmaktadır. Eğitim seviyesi, gelir durumu yükseldikçe hastaların farkındalıkları artmakta ve öz yönetim becerileri gelişerek hastanın konfor düzeyini etkilediği düşünülmektedir.

Litaratürde HD tedavisi alan hastaların konfor düzeylerine ilişkin çalışmalara bakıldığında konfor düzeyinin girişim yapılmadan önce düşük seviyede olduğu görülmektedir ${ }^{31,32}$. Çalışmamızda hemodiyaliz hastalarının konfor düzeyinin 
Tablo 3. Hemodiyaliz Hastalarının Tanımlayıcı Özellikleri ve Hemodiyalizde Konfor Ölçeği Puan Ortalamalarının Karșılaştırılmas

\begin{tabular}{|c|c|c|c|c|c|c|c|}
\hline Cinsiyet & $\mathrm{n}=\mathbf{2 6 2}$ & Rahatlama Alt Boyut-Puan Ortalaması \pm SS & $\mathbf{p}$ & Üstesinden Gelme Alt Boyut- Puan Ortalaması $\pm S S$ & p & Ölçek Puan Ortalaması $\pm S S$ & $\mathbf{p}$ \\
\hline Kadın & 106 & $8.97 \pm 3.38$ & \multirow[t]{2}{*}{0.01} & $15.56 \pm 5.19$ & \multirow[t]{2}{*}{0.02} & $24.53 \pm 7.26$ & \multirow[t]{2}{*}{0.49} \\
\hline Erkek & 156 & $9.30 \pm 3.91$ & & $16.32 \pm 4.52$ & & $25.62 \pm 6.85$ & \\
\hline \multicolumn{8}{|l|}{ Yaş } \\
\hline 39 ve altı & 26 & $8.84 \pm 3.74$ & \multirow[t]{4}{*}{0.83} & $18.07 \pm 4.90$ & \multirow[t]{4}{*}{0.40} & $26.92 \pm 7.14$ & \multirow[t]{4}{*}{0.65} \\
\hline $40-59$ & 80 & $9.47 \pm 3.76$ & & $16.43 \pm 4.25$ & & $25.91 \pm 6.62$ & \\
\hline $60-69$ & 80 & $9.11 \pm 3.72$ & & $15.08 \pm 5.07$ & & $24.20 \pm 7.46$ & \\
\hline 70 ve üzeri & 76 & $9.01 \pm 3.68$ & & $15.84 \pm 4.87$ & & $24.85 \pm 6.87$ & \\
\hline \multicolumn{8}{|l|}{ Medeni Durum } \\
\hline Bekar & 59 & $9.02 \pm 3.67$ & 0.56 & $16.83 \pm 4.76$ & 0.25 & $24.47 \pm 6.39$ & 0.31 \\
\hline \multicolumn{8}{|l|}{ Eğitim Durumu } \\
\hline Okur yazar değil & 17 & $9.41 \pm 4.28$ & \multirow[t]{5}{*}{0.11} & $16.70 \pm 5.16$ & \multirow[t]{5}{*}{0.48} & $26.11 \pm 8.25$ & \multirow[t]{5}{*}{0.21} \\
\hline ilkokul & 94 & $8.44 \pm 3.29$ & & $15.43 \pm 4.80$ & & $23.88 \pm 6.60$ & \\
\hline Ortaokul & 22 & $9.00 \pm 4.26$ & & $15.81 \pm 4.76$ & & $24.81 \pm 7.73$ & \\
\hline Lise & 44 & $9.20 \pm 3.89$ & & $17.06 \pm 5.21$ & & $26.27 \pm 7.51$ & \\
\hline Üniversite & 85 & $10.02 \pm 3.71$ & & $16.20 \pm 4.42$ & & $26.22 \pm 6.40$ & \\
\hline \multicolumn{8}{|l|}{ Sosyal Güvence } \\
\hline Evet & 250 & $9.22 \pm 3.71$ & 0.23 & $16.11 \pm 4.79$ & 0.13 & $25.34 \pm 7.03$ & 0.09 \\
\hline \multicolumn{8}{|l|}{ Meslek } \\
\hline Memur & 23 & $9.04 \pm 2.93$ & \multirow[t]{7}{*}{0.83} & $16.69 \pm 4.08$ & \multirow[t]{7}{*}{0.10} & $25.73 \pm 5.86$ & \multirow[t]{7}{*}{0.28} \\
\hline İşçi & 14 & $10.07 \pm 3.64$ & & $17.85 \pm 4.24$ & & $27.92 \pm 5.44$ & \\
\hline Emekli & 97 & $9.23 \pm 3.95$ & & $16.10 \pm 4.99$ & & $25.34 \pm 7.65$ & \\
\hline Ev hanımı & 72 & $8.70 \pm 3.52$ & & $15.19 \pm 4.98$ & & $23.90 \pm 7.05$ & \\
\hline Serbest meslek & 17 & $8.70 \pm 3.58$ & & $15.94 \pm 4.39$ & & $24.64 \pm 6.56$ & \\
\hline İşsiz & 13 & $9.53 \pm 3.82$ & & $18.76 \pm 5.50$ & & $28.30 \pm 8.22$ & \\
\hline Diğer & 26 & $9.87 \pm 4.11$ & & $14.66 \pm 3.85$ & & $24.54 \pm 5.35$ & \\
\hline \multicolumn{8}{|l|}{ Gelir Durumu } \\
\hline Düşük & 51 & $9.03 \pm 3.64$ & \multirow[t]{3}{*}{0.35} & $15.35 \pm 3.87$ & \multirow[t]{3}{*}{$<0.001$} & $24.39 \pm 5.73$ & \multirow[t]{3}{*}{0.01} \\
\hline Orta & 184 & $9.05 \pm 3.78$ & & $15.81 \pm 4.80$ & & $24.87 \pm 7.08$ & \\
\hline Yüksek & 27 & $10.14 \pm 3.21$ & & $18.62 \pm 5.70$ & & $28.77 \pm 7.99$ & \\
\hline
\end{tabular}

Değerler ortalama \pm standart sapma olarak sunulmuștur

SS: Standart Sapma

*p: One-way ANOVA 
Tablo 4. Hemodiyaliz Hastalarının Hastalı̆a Illişkin Özellikleri ve Hemodiyalizde Konfor Ölçeği Puan Ortalamalarının Karşılaştırılması

\begin{tabular}{|c|c|c|c|c|c|c|c|}
\hline Vasküler Giriş Yolu & $n=262$ & $\begin{array}{l}\text { Rahatlama Alt Boyut- } \\
\text { Puan Ortalaması } \pm S S\end{array}$ & $* p$ & $\begin{array}{l}\text { Üstesinden Gelme Alt } \\
\text { Boyut- Puan Ortalaması } \pm S S\end{array}$ & $*_{p}$ & Ölçek Puan Ortalaması $\pm S S$ & $* p$ \\
\hline Katater & 84 & $9.00 \pm 3.60$ & \multirow[t]{3}{*}{0.44} & $15.22 \pm 4.69$ & \multirow[t]{3}{*}{0.03} & $24.22 \pm 7.07$ & \multirow[t]{3}{*}{0.26} \\
\hline Fistül & 172 & $9.30 \pm 3.77$ & & $16.26 \pm 4.79$ & & $25.57 \pm 6.99$ & \\
\hline Greft & 6 & $7.50 \pm 3.01$ & & $19.83 \pm 5.07$ & & $27.33 \pm 7.17$ & \\
\hline \multicolumn{8}{|l|}{$\begin{array}{l}\text { Haftalık Seans } \\
\text { Sayısı }\end{array}$} \\
\hline Haftada 3 seans & 203 & $10.33 \pm 3.74$ & \multirow[t]{3}{*}{0.11} & $19.00 \pm 4.47$ & \multirow[t]{3}{*}{0.02} & $29.33 \pm 6.89$ & \multirow[t]{3}{*}{$<0.001$} \\
\hline Haftada 2 seans & 50 & $8.08 \pm 3.08$ & & $14.44 \pm 4.33$ & & $22.52 \pm 5.80$ & \\
\hline Haftada 1 seans & 9 & $9.38 \pm 3.79$ & & $16.24 \pm 4.86$ & & $25.63 \pm 7.15$ & \\
\hline \multicolumn{8}{|l|}{ Sekonder Hastalık } \\
\hline Evet & 118 & $9.21 \pm 3.82$ & \multirow[t]{2}{*}{0.86} & $15.30 \pm 4.92$ & \multirow[t]{2}{*}{0.03} & $24.51 \pm 7.34$ & \multirow[t]{2}{*}{0.16} \\
\hline Hayır & 144 & $9.13 \pm 3.62$ & & $16.59 \pm 4.65$ & & $25.72 \pm 6.73$ & \\
\hline \multicolumn{8}{|l|}{$\begin{array}{l}\text { Hemodiyaliz } \\
\text { Tedavisine Başlama } \\
\text { Zamanı }\end{array}$} \\
\hline $1-3$ yıl & 93 & $9.01 \pm 3.48$ & \multirow[t]{5}{*}{0.81} & $15.45 \pm 5.42$ & \multirow[t]{5}{*}{0.11} & $24.46 \pm 7.39$ & \multirow[t]{5}{*}{0.26} \\
\hline $4-6$ yıl & 62 & $9.01 \pm 4.12$ & & $15.70 \pm 4.22$ & & $24.72 \pm 6.36$ & \\
\hline $7-9$ yıl & 33 & $9.87 \pm 3.90$ & & $16.42 \pm 4.52$ & & $26.30 \pm 6.53$ & \\
\hline 10-12 yıl & 40 & $9.30 \pm 3.64$ & & $17.80 \pm 4.61$ & & $27.10 \pm 7.19$ & \\
\hline 13 yıl ve üzeri & 34 & $9.02 \pm 3.52$ & & $15.61 \pm 4.24$ & & $24.64 \pm 6.18$ & \\
\hline
\end{tabular}

Değerler ortalama tstandart sapma olarak sunulmuştur.

SS: Standart Sapma

*p: One-way ANOVA 
orta düzeyde olduğu saptanmıştır. Bu durumun çalışma gruplarının farklılıklarından kaynaklandığı düşünülmektedir. HD tedavisi alan hastaların konforu etkileyen faktörler belirlenip uygun hemşirelik girişimleri uygulandığında, konforun anlamlı düzeyde arttığı görülmektedir.

Hemodiyaliz hastalarında görülen semptomlar, bireyin konfor düzeyi ve yaşam kalitesini etkilemektedir. Etkin semptom kontrolü sağlanan hastalar ferahlama duygusu yaşarlar ${ }^{33}$. Çalışmamızda hastaların HDKÖ ortalamalarının orta düzeyde olduğu bulunmuştur. Çalışkan'ın (2018), üremik hastalarda kaşıntının konfor düzeyine etkisini incelediği çalışmada; hastaların konfor düzeylerini genel konfor ölçeği ile değerlendirmiş ve hemodiyaliz tedavisi alan hastaların hemodiyaliz tedavisi almayan hastalara göre yüksek konfora sahip olduğunu saptamıştır ${ }^{12}$. Hastaların hastalık ve/veya tedaviden kaynaklanan semptomlarının saptanıp, semptom yönetiminin sağlanması ile hastaların konfor düzeyine olumlu katkılarının olacağı düşünülmektedir.

\section{SONUÇ ve ÖNERILER}

Sonuç olarak, hemodiyaliz hastalarının konfor düzeyinin orta düzeyde olduğu, erkek hastaların ve gelir durumu yüksek hastaların konfor düzeyinin daha yüksek olduğu saptanmıştır. Bu sonuçlar doğrultusunda; konfor düzeylerini arttırıcı yeni çalışmalar planlanması ve alana özgü düzenlemelerin yapılması önerilmektedir.

Etik Kurul Onayı: Başkent Üniversitesi Etik Kurulu'ndan alınmıştır (Karar No: KA18/289).

Çıkar Çatışması: Bildirilmemiştir.

Finansal Destek: Yoktur.

Katılımcı Onamı: Hemodiyaliz hastalarından bilgilendirilmiş onam alınmıştır.

Yazar katkıları:

Çalışma tasarımı: GT, ÇÖE, ŞÖ, EAÇ

Veri toplama ve/veya analizi: GT, ÇÖE, ŞÖ, EAÇ

Makalenin hazırlanması: GT, ÇÖE, ŞÖ, EAÇ

Teşekkür

Çalışmaya katılan hemodiyaliz hastalarına teşekkür ederiz.

Ethics Committee Approval: Approval was obtained from Ethics Committee of Başkent University (Decision Number: KA18/289).

Confict of Interest: Not reported.

Funding: None.

Exhibitor Consent: Informed consent was obtained from patients undergoing hemodialysis.

Author contributions:

Study design: GT, ÇÖE, ŞÖ, EAÇ

Data collection and analyses: GT, ÇÖE, ŞÖ, EAÇ

Drafting manuscript: GT, ÇÖE, ŞÖ, EAÇ

Acknowledgement: We would like to thank all patienst with hemodialysis who approved to participate to the study.

\section{KAYNAKLAR}

1. Süleymanlar G. Kronik böbrek hastalığı ve yetmezliği: tanımı, evreleri ve epidemiyolojisi. Türkiye Klinikleri. 2007;3(38):1-7.
2. Daugirdas JT, Blake PG. Diyaliz el kitabı. 4.Baskı. Bozfakıoğlu S, editör. Ankara: Güneş Tıp Kitapevleri; 2010.

3. Türkiye'de Nefroloji, Diyaliz ve Transplantasyon. Türk Nefroloji Derneği Registry; 2018.

4. Claxton RN, Blackhall L, Weisbord SD, Holley JL. Undertreatment of symptoms in patients on maintenance hemodialsis. Journal of Pain and Symptom Management. 2010;39(2):211-18.

5. Scherer JS, Combs SA, Brennan F. Sleep disorders, restless legs syndrome, and uremic pruritus: diagnosis and treatment of common symptoms in dialysis patients. Am J Kidney Dis. 2017;69(1):11728.

6. Kavurmacı M, Tan M. Üremik kaşıntı ve hemşirelik bakımı. Anadolu Hemşirelik ve Sağlık Bilimleri Dergisi. 2015;18(1):57-62.

7. Azak A, Altundağ Dündar S. Kronik hemodiyaliz yetmezliği nedeniyle hemodiyaliz uygulanan hastalarda akut yorgunluk sendromu ve etkileyen faktörler. Türkiye Klinikleri J Med Sci.2012;32(6):1623-29.

8. Küçükünal A, Kıvanç Altunay i, Salman KE, Atış G. Hemodiyaliz hastalarında üremik pruritus ve yaşam kalitesi ilişkisi. Turkderm - Arch Turk Dermatol Venerology. 2015;49:(1):23-7.

9. Kıran F. Hemodiyalizin hastaların hayat kalitesine etkilerinin ölçülmesi (Yüksek Lisans Tezi). Tekirdağ: Namık Kemal Üniversitesi Sosyal Bilimler Enstitüsü; 2016.

10. Tan M, Okanlı A, Karabulutlu E, Erdem N. Hemodiyaliz hastalarında sosyal destek ve umutsuzluk arasındaki ilişkinin değerlendirilmesi. Atatürk Üniversitesi Hemşirelik Yüksekokulu Dergisi. 2005;8(2):32-9.

11. Akpolat $T$, Utaş $C$. Hemodiyaliz Hastalarında Sık Karşılaşılan Sorunları. Eds. Akpolat T, Utaş C. Hemodiyaliz hekimi el kitabı. Türk Nefroloji Derneği Yayını; 2008;20.

12. Çalışkan T, Çınar PS. Hemodiyaliz tedavisi alan ve almayan üremik hastalarda kaşıntı konforu etkiler mi?. Türk Nefroloji, Diyaliz ve Transplantasyon Hemşireleri Derneği Nefroloji Hemşireliği Dergisi. 2019;14(3):84-96.

13. Çınar YŞ. Kolcaba'nın konfor kuramı. Ege Üniversitesi Hemşirelik Yüksek Okulu Dergisi. 2011;27(2):79-88.

14. Carpenito MJL. Hemşirelik Tanıları El Kitabı. 2. Baskı. Erdemir F, çev. İstanbul: Nobel Tıp Kitapevleri; 2005.

15. Barutçu $A D$, Hakkı $A$, Sabahat $A$, Ecder HÇ. Hemodiyaliz ve böbrek nakli hastalarında anksiyete, depresyon ve yaşam kalitesinin karşılaştırılması. Turkish Journal of Nephrology. 2017;26(2):171-176.

16. Moledina DG, Perry WF. Pharmacologic treatment of common symptoms in dialysis patients: A narrative review. Semin Dialysis. 2015;28:377-83. 
17. Letchmi S, Das S, Halim H, Zakariah FA, Hassan H. Fatigue experienced by patients receiving maintenance dialysis in hemodialysis units. Nurs Health Sci. 2011;13:60-4.

18. Özyiğit S, Yıldırım Y, Karaman E. Hemodiyaliz hastalarında ağrı. Türk Nefroloji Diyaliz ve Transplantasyon Dergisi. 2016;25(1):88-94.

19. Özer Z, Yangöz ŞT. Hemodiyaliz hastalarında kanıta dayalı semptom yönetimi: bulantı ve kusma. Türkiye Klinikleri. 2018;9-15.

20. Yıldırım Y, Deniz A. hemodiyaliz hastalarında kanıta dayalı semptom yönetimi: konstipasyon. Türkiye Klinikleri. 2018;16-24.

21. Akgöz N, Arslan S. Hemodiyaliz tedavisi alan hastalarda yaşanan semptomların incelenmesi. Nefroloji Hemşireliği Dergisi. 2017;1(12).

22. Akyol A, Yurdusever S, Kırkayak A, Sifil HM, Ecder T. Hemodiyaliz Hastalarının Uyku Sorunlarına Etki Eden Faktörlerin İncelenmesi. Nefroloji Hemşireliği Dergisi. 2017;2(12).

23. Turgay G, Tutal E, Sezer S. Restless legs syndrome, sleep quality and fatigue in hemodialysis patients. Türk Nefroloji Diyaliz ve Transplantasyon Dergisi. 2018;2(2):196-203.

24. Vicdan AK. The effect of training given to hemodialysis patients according to the comfort theory. Clinical Nurse Specialist. 2020;30-7.

25. Diyaliz merkezileri yönetmeliği. Erişim Tarihi: 11 Kasım 2019. Erişim adresi: https://shgm.saglik.gov.tr/TR,53516/diyalizmerkezleri-hakkinda-yonetmelik.html

26. Akça KN, Doğan A. Hemodiyaliz hastalarının diyaliz sonrası yaşadığı sorunlar ve evde bakım gereksinimleri. Bozok Tıp Dergisi. 2011;1:15-22.

27. Şahin ON, Çınar PS, Kartal A. Ölçek geliştirme çalışması. Nefroloji Hemşireliği Dergisi. 2017;2(12):68-77.

28. Turgay G, Tutal E, Sezer S. Hemodiyaliz Hastalarının Günlük Yaşam Aktiviteleri, Yeti Yitimi, Depresyon ve Komorbidite Yönünden Değerlendirilmesi. Türk Nefroloji Diyaliz ve Transplantasyon Dergisi, 2017;26(3):311-6.

29. Melo GAA, Aguiar LL, Silva RA, Quirino GS, Pinheiro AKB, Caetano JA. Factors related to impaired comfort in chronic kidney disease patients on hemodialysis. Rev Bras Enferm. 2019;72(4):889-95.

30. Estridge KM, Morris DL, Kolcaba K, Winkelman C. Comfort and fluid retention in adult patients receiving hemodialysis. Nephrology Nursing Journal. 2018;45(1);25-33,60.

31. Tabiee S, Momeni A, Alireza SS. The effects of comfort-based interventions (back massage and patient and family education) on the level of comfort among hemodialysis patients. Mod Care J. 2017;14(3):64-87.

32. Isnaini N, Hidayati $T$, Sumaryani $S$. effect of combination of slow deep breathing and ice therapy towards comfort level in arteriovenous fistula insertion of hemodialysis patients in pku muhammadiyah hospital yogyakarta nur. Indonesian Journal of Clinical Pharmacy. 2018;7(1);45-51.

33. Süleymanlar $\mathrm{G}$, Utaş $\mathrm{C}$, Arinsoy $\mathrm{T}$, Ateş $\mathrm{K}$, Altun BA. Population-basedsurvey of chronic renal disease in Turkey the CREDIT study. Nephrology Dialysis Transplantation. 2011;26(6):1862-71. 